\title{
The Language Style of Hope in La Tahzan
}

\section{Syazwani binti Mohd Mutaridi, Khazri bin Osman}

To Link this Article: http://dx.doi.org/10.6007/IJARBSS/v9-i7/6179

DOI: $10.6007 /$ IJARBSS/v9-i7/6179

Received: 25 May 2019, Revised: 27 June 2019, Accepted: 20 June 2019

Published Online: 14 July 2019

In-Text Citation: (Mutaridi \& Osman, 2019)

To Cite this Article: Mutaridi, S. binti M., \& Osman, K. bin. (2019). The Language Style of Hope in La Tahzan. International Journal of Academic Research in Business and Social Sciences, 9(7), 798-804.

\section{Copyright: (c) 2019 The Author(s)}

Published by Human Resource Management Academic Research Society (www.hrmars.com)

This article is published under the Creative Commons Attribution (CC BY 4.0) license. Anyone may reproduce, distribute, translate and create derivative works of this article (for both commercial and non-commercial purposes), subject to full attribution to the original publication and authors. The full terms of this license may be seen

at: $\underline{\text { http://creativecommons.org/licences/by/4.0/legalcode }}$

Vol. 9, No. 7, 2019, Pg. 798 - 804

Full Terms \& Conditions of access and use can be found at http://hrmars.com/index.php/pages/detail/publication-ethics 


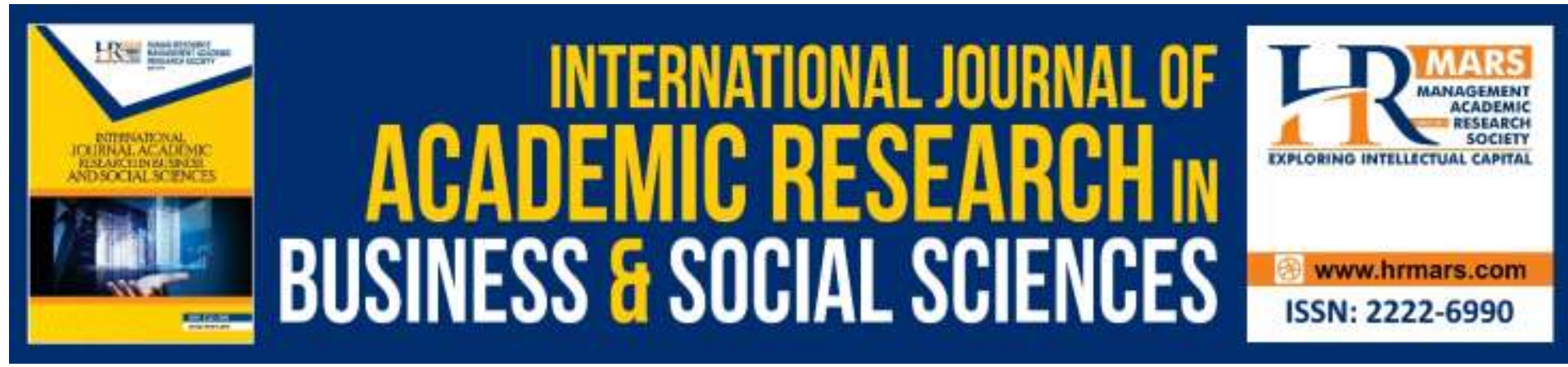

\title{
The Language Style of Hope in La Tahzan
}

\section{Syazwani binti Mohd Mutaridi, Khazri bin Osman}

Da'wah and Leadership Studies, Faculty of Islamic Studies, National University of

Malaysia

Email: syazwanimutaridi@gmail.com, khazri@ukm.edu.my

\begin{abstract}
'Aid al-Qarni is a famous da' $i$ that has already contributed a lot within his writings and talks. This paper will focus on the usage of al-Raja as one of the language styles in the Arabic language that carries a meaning of hope in a book titled La Tahzan by 'Aid alQarni. However, al-Raja in this context refers to putting a fully hope to Allah SWT and avoiding despair. This is because the language style used plays an important role in order to deliver any messages. For example, when we face any troubles, this al-Raja is needed in order to make sure that we put a very high hope to Allah SWT. Besides, 'Aid al-Qarni also mentioned some useful and effective ways in order to avoid ourselves from being despair when facing any troubles as there must be any way to solve them. This study uses a qualitative approach to process and analyses data. This study also is limited in the scope of the language style on al-Raja only that uses words of 'asa (عسى) and la'alla (لعل).
\end{abstract}

Keyword: Language Style, al-Raja', La Tahzan, Balaghah, Style, Hope.

\section{Introduction}

Balaghah in term of knowledge means an ability to describe what is in the mind with a clear meaning and true structure. It is related to arts and also including all the variety of style and beautiful expression. Beside that, balaghah in this term also refers to rhetoric. Gorys Keraf comes with a meaning that defines rhetoric as a certain technique of using language as a form of arts whether in speeches or writings based on a certain good form of knowledge (Keraf, 1984).

The language style used also must to align with what to deliver so that the receiver can receive the messages correctly. There are also aesthetic elements that should be connected by a poet so that he or she can come out with a good and nice poems (Osman \& Mohamed, 2018). If the language style used is good, therefore the message also can be delivers easily to receiver or reader. According to (Yunusa, 2014) a writer, to a large extent, is a teacher passing lessons to his readers or a righter correcting his audience through his writings. So, this study is about the usage of alRaja language style in the work of 'Aid al-Qarni, La Tahzan. 
The language of $d a^{\prime} w a h$ is important to be understood because it can guide any preacher in delivering $d a^{\prime}$ wah correctly according to the condition of the mad'u or da'wah targets (Fuad, 2015). When $d a^{\prime}$ wah $h$ is been delivered in form of writing, the wisdom of it can be seen within good writing, attractive and easy to be understood besides uses a medium level of language and also can increase the spirit of the reader to do good things just what had been written. So, the language style can be concluded as a certain way in using language to deliver any thoughts and feelings through the ways that show the identities of the writer. It is also important in understanding a text or a book so that it can be delivered directly to the readers. So, that's why this book, La Tahzan had been chosen in looking al-Raja' that has been used by its writer, 'Aid al-Qarni.

He also was been imprisoned because of 50 phrases of poems he wrote about politics. So, this book was written by him in prison. There, he managed to write 100 pages of his book while after been released he continued until it finished (Tabari, 2009). This book, La Tahzan is one of his famous and bestseller books. In addition, this book also had been translated to other 29 languages (Bakri, 2016). Al-Qarni always uses poems in his writing and he named his book by La Tahzan adapted from a Prophet Muhammad SAW saying (hadith) to his companion, Abu Bakr al-Siddiq when he was very scared as they were hiding in Tsur cave: "La tahzan, innallah ma'ana" (Don't be sad, Allah is with us). Allah also says in Surah al-Tawbah, verse 40: :

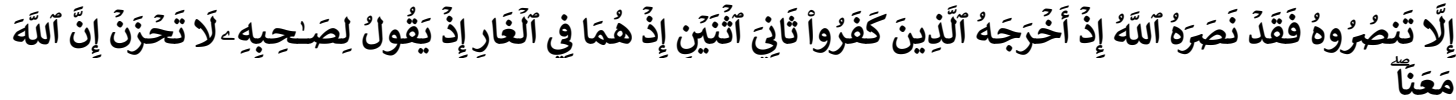

Translation:

If ye help not (your leader), (it is no matter): for Allah did indeed help him, when the Unbelievers drove him out: he had no more than one companion; they two were in the cave, and he said to his companion, "Have no fear, for Allah is with us"

(Al-Quran, al-Tawbah 9:40)

From the ayah above, we can understand that Allah SWT commands every single of His servants to not to lose hope. So, all his servants must put hope on only to Him. According to (Zaidan, 2009), we as a Muslim cannot easily to lose hope because it will block our way to Allah and only the unbelievers have this type of attitude.

\section{Problem Statement}

Al-Raja refers to a condition of hopefulness. This occurs when somebody feels that there must be a new day or hope for a better tomorrow. This hope gives the person a condition of inner calmness in order to get something good regardless of fear in his or herself. Those who do not have any hope will despair and getting his or herself lost. That's why Allah SWT says to all the true believers not to lose hope and Allah disgrace those who are losing hope from His mercy.

La Tahzan is one of the works of 'Aid al-Qarni. This book was been written as a spirit booster for those who are facing a lot of problems in their life. Then, fully putting hope to Allah SWT in order to find the way out. So, this type of language style 
of al-Raja is important to be studied in this book. Then also the relationship and role with the messages that wanted to be delivered by the writer. Finally, this way can be a guide for any $d a^{\prime} i$ in order to make his or her mad'u put the true hope on Allah SWT.

\section{Research Methodology}

This research uses a qualitative approach in order to process and analyse data. So, La Tahzan was been used as research subject to be analysed. Besides, the researcher also used any type of research matter about this topic whether it is in a form of writing or electronic media that can be used to strengthen the research questions and the theme focused by the researcher. As just mentioned before, the book titled La Tahzan had been chosen as the main subject in this research in order to identify the language style used in term of al-Raja'.

\section{Discussion}

\section{Faith As Way Towords Salvation}

Allah SWT says in the Quran:

Translation:

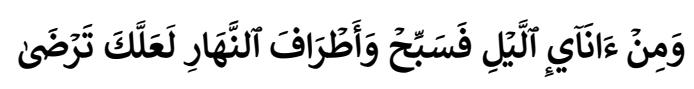

... and celebrate (constantly) the praises of the Lord, before the rising of the sun, and before its setting; yea, celebrate them for part of the hours of the night, and at the sides of the day: that thou mayest have (spiritual) joy.

(Al-Quran, Taha 20:130)

Surely those who suffer are those who are lack of iman. They always be in misery, pain, worse and disgrace. There is no anyone who can make soul happy, purify it and throw out the misery from a person except the real only faith to Allah SWT. Allah says in surah Taha:

Translation

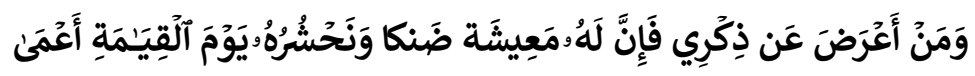

But whosoever turns away from My Message, verily for him is a life narrowed down, and We shall raise him up blind on the Day of Judgment.

(Al-Quran, Taha 20:124)

Besides, the heart that become afraid after mentioning the name of Allah also can give calmness because only with zikrullah, can make our heart calm. The heart that afraid when listening to His names, promises and threat also can make us avoid any wrong doings and also increase our spirit to obey Him. One of the zikrullah for the believers is the reading of the Quran. So, this is clear that only faith is the way towards salvation in this worldly life and hereafter.

According to Ibnu Katsir (2003), the phrase "wa min anaillayl fasabbih" means "for part of the hours of the night you have to perform tahajjud prayer". Then, some of the commentators say: "...and during the night means maghrib and isya' prayer". While the phrase "wa atrafan nahar" means the day. The word "al-Nahar" also refers to a type. So, every day have their end. Then, the word came with plural form refer to every day (Qurthubi, 2010). So, the word la'allaka tarda" means that thou (Prophet Muhammad SAW) mayest have (spiritual) joy. While the word "Ia'alla" here means so that. For this word, Qurthubi (2010) define it as fathah in $t a^{\prime}$ means so that you 
(Prophet Muhammad SAW) can get your reward for what you have done ('amal). But, al-Kisai and Abu Bakr from "Asim read "turda" with dhommah which means so that you will be rewarded with what you please with it.

\section{Do Not Be Sad as Sadness Can Bring Suffers}

Alllah SWT says:

Translation:

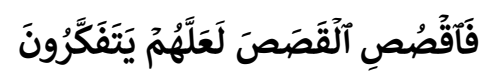

So relate the story; perchance they may reflect.

(Al-Quran, al-A'raf 7:176)

The story of Bal'am bin Ba'ura' and the parable about the wise man who is slipped away from his knowledge. According to Ibnu Katsir (2008) the lesson for us is no to be like him until been gone astray and far from Allah's mercy. Allah SWT also commands Prophet Muhammad SAW to read this news to his people who were received His words (Qutb, 2000). There is no human being who is always feel good and vice versa. Ther is a time for happiness and sadness in human life. Allah tells about the condition of Prophet Muhammad SAW and his companions during the War of Uhud. The war when Muslims lost to Quraisy . Allah says in the Quran:

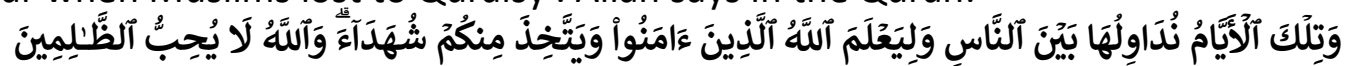
Translation:

Such days (of varying fortunes) We give to men and men by turns: that Allah may know those that believe, and that He may take to Himself from your ranks Martyr-witnesses (to Truth). And Allah loveth not those that do wrong.

(Al-Quran, Ali Imran 3:140)

Allah has created everything in this world with a specific purpose. Each has its own purpose. God created human happiness so happy to know that they appreciate the joy of gratitude and giving. While tested with grief is to bow before God and does not boast, so complain and hope only in God. As His servants who believe, stay away from excessive sad because it will damage yourself.

Allah says:

Translation:

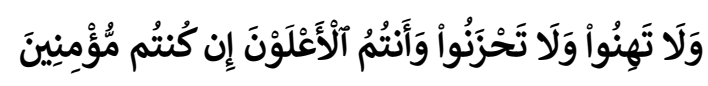

So lose not heart, nor fall into despair: For ye must gain mastery if ye are true in Faith.

(Al-Quran, Ali Imran 3:139)

Prophet Muhammad SAW also pray to Allah SWT in order to avoid from being sad:

Translation:

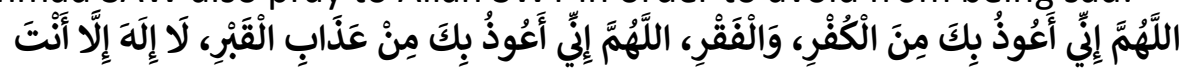

O Allah, I seek refuge in You from disbelief and poverty; O Allah, I seek refuge in You from the punishment of the grave. There is no God but Thee.

(Abu Dāwud, Sunan Abu Dāwud, Bab Mā Yaqūl Iza Asbaha) 
Through this ayah, (Qarni, 1999) defines la'alla refers to the meaning to be. Where this ayah expect the earlier story to be a lesson so that people can think by themselves. It also refers to a hope that human can think the lesson of the previous stories that have been recorded in the Quran. Whereas, al-qasas is meant here is the stories in the Quran. In addition, in this ayah there is a word "yatafakkar" which means to think. So, as a human being, we should make the past stories as a guide in our daily lives.

\section{Conclusion}

From this research, we can conclude that:

1. The beauty of the style that is used to symbolize a situation can be seen through the poems and verses from the Quran that is mentioned in every theme of al-Qarni's work.

2. The word 'asa and la'alla that been discussed in this paper means hope. It also explains the meaning and purpose of its own. Al-Qarni in his literary greatness can not be denied because of his works are alway able to attract the reader's emotions.

3. The results of this study can be used as a reference that can be exploited by $d a^{\prime} i$ in preaching even by using the elements of hope.

\section{Recommendations}

There are some of the recommendation that can be drawn from this research:

1. The da'i should use this type of methodology (hope) that mentioned in La Tahzan in facing new challenges in $d a^{\prime}$ wah nowadays.

2. The $d a^{\prime} i$ should emphasize the importance of hope in mad'u soul especially hope to Allah SWT.

\section{References}

\section{Al-Quran}

Bakri, K. B. (2016). Obat Mujarab Anti Sedih. Majalah Gatra.

Fuad, Z. (2015). Pendekatan Bahasa dalam Dakwah (Satu Kajian Dari Perspektif alQuran). E-Jurnal Penyelidikan dan Inovasi Jilid II, 14-25.

Ismail, Al-Fida, I. B. (2003). Tafsir Ibn Kathir. Riyadh: Maktaba Dar-us-Salam.

Katsiir, M. M. (2008). Tafsir Ibnu Katsir. Bogor: Pustaka Ibnu Katsir.

Keraf, G. (1984). Diksi dan Gaya Bahasa. Jakarta: Gramedia Pustaka Utama.

Osman, K., \& Mohamed, F. (2018). The Aesthetics in the Poems of Patience of Imam Shafi'i Rahimahullah. International Journal of Academic Research in Business \& Social Sciences, 1874-1882.

Qarni, '. A. (1999). La Tahzan. Beirut, Lubnan: Dar Ibn Jazm.

Qurthubi, S. I. (2010). Tafsir al-Qurthubi. Jakarta: Pustaka Azzam.

Qutb, A. S. S. (2000). Tafsir Fi Zilalil Qur'an. Kota Bharu, Kelantan: Pustaka Aman Press Sdn.Bhd.

Tabari, A. J. (2009). Tafsir Ath-Thabari. (S. Muhammad Syakir, \& S. Muhammad Syakir, Trans.) Jakarta: Pustaka Azzam. 
Yunusa, J. M. (2014). Contemporary Arabic Novelist and Social Responsibility: A Peep Into Al-Hijri's Al-Sayyid Al-Raees. Journal of Islamic Studies and Culture, Vol. 2, No. 1, 13-29.

Zaidan, K. (2009). Dasar-dasar Ilmu Da'wah. Shah Alam, Selangor: Dewan Pustaka Fajar. 